\title{
Recent Advances in Synthesis and Applications of Carbon-Doped $\mathrm{TiO}_{2}$ Nanomaterials
}

\author{
Li Hua ${ }^{1}$, Zhengliang Yin ${ }^{2}$ and Shunsheng Cao ${ }^{2, *}$ \\ 1 Yangzhou Polytechnic Institute, College of Chemical Engineering, Yangzhou 225127, China; \\ huali795@sohu.com \\ 2 Research School of Polymer Materials, School of Materials Science and Engineering, Jiangsu University, \\ Zhenjiang 212013, China; ZhengLiangYin2020@126.com \\ * Correspondence: sscao@ujs.edu.cn; Tel.: +86-0511-88790191
}

Received: 26 October 2020; Accepted: 28 November 2020; Published: 8 December 2020

check for updates

\begin{abstract}
TiO}_{2}$ has been widely used as a photocatalyst and an electrode material toward the photodegradation of organic pollutants and electrochemical applications, respectively. However, the properties of $\mathrm{TiO}_{2}$ are not enough up to meet practical needs because of its intrinsic disadvantages such as a wide bandgap and low conductivity. Incorporation of carbon into the $\mathrm{TiO}_{2}$ lattice is a promising tool to overcome these limitations because carbon has metal-like conductivity, high separation efficiency of photogenerated electron/hole pairs, and strong visible-light absorption. This review would describe and discuss a variety of strategies to develop carbon-doped $\mathrm{TiO}_{2}$ with enhanced photoelectrochemical performances in environmental, energy, and catalytic fields. Emphasis is given to highlight current techniques and recent progress in C-doped $\mathrm{TiO}_{2}$-based materials. Meanwhile, how to tackle the challenges we are currently facing is also discussed. This understanding will allow the process to continue to evolve and provide facile and feasible techniques for the design and development of carbon-doped $\mathrm{TiO}_{2}$ materials.
\end{abstract}

Keywords: carbon doping; $\mathrm{TiO}_{2}$; pollutant degradation; electrochemical application; review

\section{Introduction}

Environmental pollution and energy crisis have been the most urgent issues in recent years [1-5]. Photocatalysis is a promising strategy to alleviate, and even work out these problems because it could efficiently decompose organic pollutants or produce chemical energy using semiconductors and renewable solar energy [5-7]. Titanium dioxide $\left(\mathrm{TiO}_{2}\right)$, as one kind of nontoxic, high stable, and low-cost materials, has received special interest in environmental, catalysis, and energy areas [8-11]. However, the photocatalytic efficiency of pure $\mathrm{TiO}_{2}$ is not enough up to meet practical needs because of its wide bandgap $(\sim 3.2 \mathrm{eV})$, and the fast recombination of photoinduced charge pairs, leading to a considerable energy consumption, poor visible-light photocatalytic activity, and low quantum efficiency $[9,12,13]$. Therefore, how to significantly promote charge separation is of significance in meeting practical needs.

Tremendous efforts have been devoted to varying the morphology, structure, and chemical composition of $\mathrm{TiO}_{2}$ by doping metal and/or nonmetal elements, surface sensitization, and coupling with narrow band-gap semiconductors [8,12-14]. Among these strategies, metal doped $\mathrm{TiO}_{2}$ usually suffers from photocorrosion, poor stability, low doping amount, and no noticeable change in the band gap of $\mathrm{TiO}_{2}$ [8,14-16], while $\mathrm{TiO}_{2}$ is coupled with other semiconductors, the additional cost and undermined stabilization have also disadvantageous effects on the practical employment of $\mathrm{TiO}_{2}$ composites [15]. Notably, non-metal doping has attracted much more interest of investigators than metal doping in improving the photoelectronic performances of $\mathrm{TiO}_{2}$ and in shifting its absorption edge to the long wavelength region $[13,14]$. Especially, carbon doped $\mathrm{TiO}_{2}$ manifests promising 
advantages beyond other non-metal doping, which may be ascribed to following aspects $[12,14,17-20]$ : (1) carbon holds metallic conductivity; (2) carbon serves as a trapping center and transport channel for photogenerated electrons, promoting separation efficiency of photoinduced electron/hole pairs; and (3) carbon can also act as a sensitizer to sensitize $\mathrm{TiO}_{2}$ under visible light irradiation, thus aggregating a number of thermal energy, facilitating charge transfer from the bulk of $\mathrm{TiO}_{2}$ into oxidation reaction sites, and further generating lots of active species. Notably, carbon is always indicated that it can be permeated to the lattice of $\mathrm{TiO}_{2}$ so as to substitute a lattice $\mathrm{O}$ or $\mathrm{Ti}$ atom, and then form a Ti-C or C-O-Ti bond, which produces a hybrid orbital just above the valence band of $\mathrm{TiO}_{2}$ and bestows a significant enhancement in visible-light driven photocatalytic activity. Therefore, coupling $\mathrm{TiO}_{2}$ with carbon materials including activated carbon [21,22], carbon nanofibers [23,24], carbon nanotubes [25-27], carbon sphere [28,29], carbon dot [30,31], graphene [32-34], and carbon doping [8,9,14,35] have been widely investigated and proved to hold significant potential over other types of modification methods in environmental, energy, and biomedical fields.

Among carbon materials, carbon doping has been attracting special interest because the introduction of carbon atom causes an electron coupling effect between carbon and $\mathrm{TiO}_{2}$ or introduces a localized occupied state into $\mathrm{TiO}_{2}$ to narrow the bandgap of $\mathrm{TiO}_{2}[8,9,14]$. For example, Zegeye et al. [36] developed hybrid carbon-doped $\mathrm{TiO}_{2} / \mathrm{S}$ composite as a positive electrode material for lithium-sulfur batteries, manifesting enhanced cycle stability and rate performance. Our groups designed and constructed several carbon-doped $\mathrm{TiO}_{2}$-based materials such as C-doped $\mathrm{TiO}_{2}$ hollow spheres [14], C-doped $\mathrm{TiO}_{2}$ single-crystal nanorods [8], and hierarchical $\mathrm{SiO}_{2} @ \mathrm{C}$-doped $\mathrm{TiO}_{2}$ hollow spheres [9]. Further investigation found that the as-synthesized carbon-doped $\mathrm{TiO}_{2}$ materials manifested superior photocatalytic performance toward the degradation of organic pollutants (RhB-. MB, MV, 4-NP, etc.).

In the past several years, many encouraging achievements have been exhibited in the research area of $\mathrm{TiO}_{2}$-based materials. Especially, carbon-doped $\mathrm{TiO}_{2}$ composites have attracted an increasing attention in environmental and energy science because they can exhibit sizeable potential superiorities as adsorbent, support, and sensitizer, promoting photogenerated electrons migrating to semiconductors $[7,37]$. In this review, we systematically summarize the currently available synthesis strategies and applications of carbon-doped $\mathrm{TiO}_{2}$ materials. Notably, we further highlight recent progress in the design and construction of carbon-doped $\mathrm{TiO}_{2}$ composites with a multifunctional nature. Finally, challenges and outlooks are outlined and discussed, identifying prospective areas for related research in this field.

\section{Characterization Techniques for the Formation of Carbon Doping}

\subsection{XPS Analysis}

Carbon-doped $\mathrm{TiO}_{2}$ is that carbon element is incorporated into the lattice of $\mathrm{TiO}_{2}$ by replacing some of the lattice titanium or oxygen atoms, forming $\mathrm{Ti}-\mathrm{O}-\mathrm{C}$ or $\mathrm{Ti}-\mathrm{C}$ bond, respectively. Therefore, $\mathrm{X}$-ray photoelectron spectroscopy (XPS) measurement was widely used to obtain the information of $\mathrm{Ti}-\mathrm{O}-\mathrm{C}$ or Ti-C bond because XPS has a perfect match of its probe length (about $10 \mathrm{~nm}$ ) to the size of particles, and exhibits its ability to probe the chemical identity of the elements present [38]. Therefore, the binding energy of C1s according to XPS analysis is considered as a solid evidence to confirm the formation of carbon doping $[8,9,14,39-42]$, as shown in Table 1 . This section focuses on addressing and discussing the difference of two chemical bonds ( $\mathrm{Ti}-\mathrm{O}-\mathrm{C}$ or $\mathrm{Ti}-\mathrm{C}$ band) as an evidence to distinguish whether carbon is incorporated into the lattice of $\mathrm{TiO}_{2}$, adsorbed on the surface, or the interstitial position of the $\mathrm{TiO}_{2}$ lattice. 
Table 1. The $\mathrm{C} 1$ s peak and typical synthetic method of $\mathrm{C}$-doped $\mathrm{TiO}_{2}$ materials.

\begin{tabular}{|c|c|c|c|}
\hline Catalyst & C1s Peak & Synthesis Methods & Reference \\
\hline Carbon@ $\mathrm{TiO}_{2}$ hollow spheres & $\mathrm{Ti}-\mathrm{O}-\mathrm{C}$ bond & Template-derected method & [12] \\
\hline Carbon- $-\mathrm{TiO}_{2}$ nanotubes & $\mathrm{Ti}-\mathrm{O}-\mathrm{C}$ bond & Template-derected method & [13] \\
\hline Carbon-doped $\mathrm{TiO}_{2}$ on $\mathrm{TiC}$ structure & $\mathrm{Ti}-\mathrm{O}-\mathrm{C}$ bond & TiC calcination & [15] \\
\hline C-doped $\mathrm{TiO}_{2}$ & $\mathrm{Ti}-\mathrm{O}-\mathrm{C}$ bond & Sol-microwave & [43] \\
\hline Carbon-Doped $\mathrm{TiO}_{2} / \mathrm{MCF}-\mathrm{F}$ & $\mathrm{Ti}-\mathrm{O}-\mathrm{C}$ bond & Hydrothermal synthesis & [5] \\
\hline $\mathrm{TiO}_{2} / \mathrm{NCQD}$ composites & $\mathrm{Ti}-\mathrm{O}-\mathrm{C}$ bond & TiC calcination & {$[44]$} \\
\hline $\mathrm{Fe}_{3} \mathrm{O}_{4} @ \mathrm{C} @ \mathrm{~F}-\mathrm{TiO}_{2}$ & $\mathrm{Ti}-\mathrm{O}-\mathrm{C}$ bond & Hydrothermal synthesis & [45] \\
\hline $\mathrm{Pd} / \mathrm{TiO}_{2}-\mathrm{C}$ & $\mathrm{Ti}-\mathrm{O}-\mathrm{C}$ bond & Solvothermal synthesis & [46] \\
\hline C-doped $\mathrm{TiO}_{2}$ nanoparticles & Ti-C bond & Hydrothermal synthesis & [47] \\
\hline C-doped $\mathrm{TiO}_{2} @ \mathrm{~g}-\mathrm{C}_{3} \mathrm{~N}_{4}$ nanospheres & Ti-C bond & Hydrothermal synthesis & [48] \\
\hline $\mathrm{C}-\mathrm{TiO}_{2}$ modified $\mathrm{g}-\mathrm{C}_{3} \mathrm{~N}_{4}$ & Ti-C bond & TiC calcination & [49] \\
\hline MC-Meso C-doped $\mathrm{TiO}_{2} / \mathrm{S}$ & Ti-C bond & Hydrothermal synthesis & [36] \\
\hline $\mathrm{N} \& \mathrm{C}$ doped $\mathrm{TiO}_{2}$ supported $\mathrm{Pt}$ & Ti-C bond & Hydrothermal synthesis & [50] \\
\hline $\mathrm{C}-\mathrm{TiO}_{2} / \mathrm{g}-\mathrm{C}_{3} \mathrm{~N}_{4}$ composite & Ti-C bond & TiC calcination & [51] \\
\hline $\mathrm{C}-\mathrm{H}-\mathrm{TiO}_{2}$ & Ti-C bond & TiC calcination & [40] \\
\hline Carbon-doped $\mathrm{TiO}_{2}$ nanorods & Ti-C bond & Template-directed method & [8] \\
\hline $\mathrm{SiO}_{2} @$ C-doped $\mathrm{TiO}_{2}$ hollow spheres & Ti-C bond & Template-directed method & [9] \\
\hline C-doped Hollow $\mathrm{TiO}_{2}$ & Ti-C bond & Template-directed method & [14] \\
\hline C-doped porous $\mathrm{TiO}_{2}$ & Ti-C bond & Template-directed method & [42] \\
\hline
\end{tabular}

\subsubsection{The Existence of Ti-O-C Bond}

XPS measurement was usually employed to obtain the chemical state and binding energy of carbon-doped or carbon-decorated $\mathrm{TiO}_{2}$ composites, ascertaining fundamental information on the interaction between $\mathrm{C}$ dopant and $\mathrm{TiO}_{2}[5,8,35,40,41,48,50-53]$. When carbon is doped into the $\mathrm{TiO}_{2}$ lattice by replacing the lattice titanium, the Ti-O-C bond can be observed in the $\mathrm{C} 1$ s spectra, as shown in Figure 1. Therefore, many investigators believe that the existence of the Ti-O-C bond can be effective evidence for ascertaining carbon doping in their as-synthesized $\mathrm{TiO}_{2}$-based materials $[16,36,37]$. For example, Qi et al. [5] prepared carbon-doped $\mathrm{TiO}_{2} / \mathrm{MCF}-\mathrm{F}$ composite according to the observation of Ti-O-C bonds in XPS spectra of C1s. Li et al. [54] reported a novel method for the preparation of carbon-doped $\mathrm{TiO}_{2}$ composites according to the formation of the Ti-O-C bond located at $288.4 \mathrm{eV}$. Similarly, S. Ivanov and coworkers [55] insisted that the existence of the Ti-O-C structure could be used as evidence for confirming the formation of $\mathrm{C}$-doped $\mathrm{TiO}_{2}$. However, the existence of the $\mathrm{Ti}-\mathrm{O}-\mathrm{C}$ bond is not completely ascribed to the existence of carbon doping. In most cases, surface and/or interstitial amorphous carbonate dopants in the $\mathrm{TiO}_{2}$ lattice also result in the formation of Ti-O-C $[15,40,41]$ because carboxyl or oxygen-containing carbon in GO sheets exhibits strong covalent binding ability to $\mathrm{TiO}_{2}[12,41,56]$, narrowing band-gap energy and prompting its visible light absorption. Accordingly, the existence of the Ti-O-C bond is not solid evidence for ascertaining carbon incorporated into $\mathrm{TiO}_{2}$ lattice, but it might be considered as a result of specifically interstitial carbon doping. Undoubtedly, more convincing evidence is required for confirming the formation of carbon doping in the $\mathrm{TiO}_{2}$ lattice $[39,53]$. 

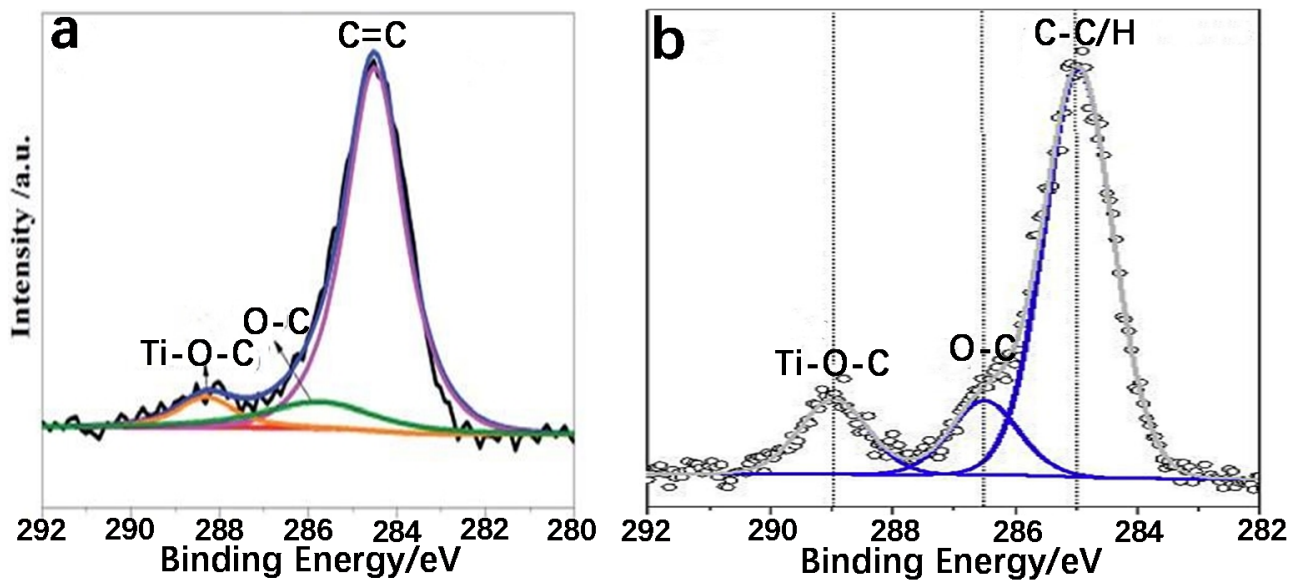

Figure 1. The existence of the Ti-O-C bond in XPS spectra of C1s (a) [54] and (b) [55].

\subsubsection{The Existence of Ti-C Bond}

When carbon is doped into the $\mathrm{TiO}_{2}$ lattice by replacing lattice oxygen, $\mathrm{Ti}-\mathrm{C}$ bond can be seen in the XPS spectra of C1s, as shown in Figure 2. it has been proved that the appearance of the Ti-C bond is considered as a solid evidence for confirming the formation of carbon doping in $\mathrm{TiO}_{2}$-based materials $[35,36,50]$. For example, Dhanasekaran P. and coworkers ascertained the formation of carbon doped titanium oxide according to the peak at $282.7 \mathrm{eV}$ (Ti-C bond) [50]. Recently, Wang et al. [35] successfully constructed carbon-doped $\mathrm{TiO}_{2}$ nanotubes by referring the binding energy of $282.0 \mathrm{eV}$ in the XPS spectra of $\mathrm{C} 1 \mathrm{~s}$. Unlike Ti-O-C bond, the existence of $\mathrm{Ti}-\mathrm{C}$ is the only result of carbon replacing oxygen in the $\mathrm{TiO}_{2}$ lattice. Clearly, the existence of the $\mathrm{Ti}-\mathrm{C}$ bond can be used as the most direct evidence for identifying the formation of carbon doping, as introduced in our previous workers $[8,9,14,42]$. Similarly, the absence of the $\mathrm{Ti}-\mathrm{C}$ bond is considered as carbon decorated $\mathrm{TiO}_{2}$ other than carbon doped $\mathrm{TiO}_{2}$, suggesting that carbon species do not substitute oxygen species and dope into the $\mathrm{TiO}_{2}$ lattice as reported in many publications $[7,12,16,18,57-60]$.

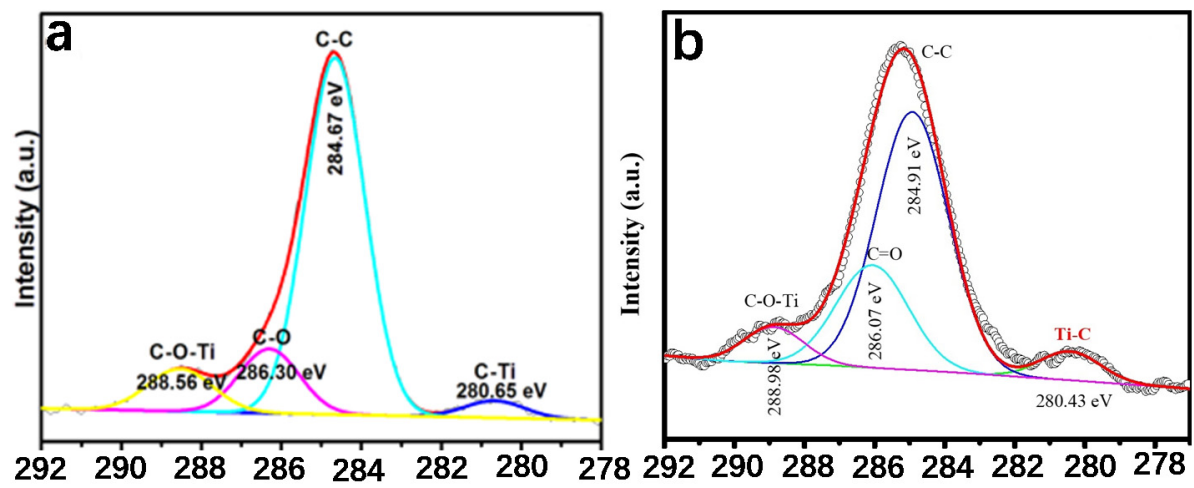

Figure 2. The existence of Ti-C bond in the XPS spectra of C1s (a) [14] and (b) [8].

\subsection{EPR Analysis}

Generally, electron paramagnetic resonance (EPR) analysis was widely used to evaluate the formation of defect sites in carbon or other dopants doped $\mathrm{TiO}_{2}$-based materials because EPR can characterize the unpaired electrons or paramagnetic centers $[40,61,62]$. If carbon doping was formed in the $\mathrm{TiO}_{2}$ lattice, a stronger EPR signatable 11 at $g=2.003 \pm 0.001$ was more able to be observed than that of pure $\mathrm{TiO}_{2}$ or undoped $\mathrm{TiO}_{2}$, which could be ascribed to the unpaired electron trapped on surface oxygen vacancies, proving that carbon element could be incorporated into the crystal lattice of $\mathrm{TiO}_{2}$-based materials [40,61]. 


\section{Strategies for the Synthesis of C-Doped $\mathrm{TiO}_{2}$ Materials}

Various strategies including hydrothermal technique, template strategy, thermal oxidation of TiC, and sol-gel process have been introduced to construct carbon-doped $\mathrm{TiO}_{2}$ materials with enhanced photoelectrochemical performances $[16,17]$, as shown in Table 1 . This section would pay attention to the description and discussion of synthetic methods involved in developing C-doped $\mathrm{TiO}_{2}$-based materials.

\subsection{Hydrothermal Method}

As a simple and mature method, the hydrothermal technique has been widely used to construct C-doped $\mathrm{TiO}_{2}$ materials because the morphology and structure of products are easily controlled by changing hydrothermal conditions $[36,39,40,63]$. In a typical hydrothermal synthesis, $\mathrm{TiO}_{2}$ precursor and carbon source are dispersed or dissolved in acidic or alkaline solution, and then the mixture is transferred into a Teflon-lined autoclave, sealed, and heated in an electric oven $\left(100-180{ }^{\circ} \mathrm{C}\right)$, forming crystallized $\mathrm{C}-\mathrm{TiO}_{2}$ structure. Finally, $\mathrm{C}$-doped $\mathrm{TiO}_{2}$ is successfully synthesized by removing organic residues via calcination under an air atmosphere. For example, mesoporous $\mathrm{C}$-doped $\mathrm{TiO}_{2}$ was able to be prepared via one-pot hydrothermal synthesis using $\mathrm{TiCl}_{4}$ and sucrose as $\mathrm{TiO}_{2}$ precursor and carbon source, respectively [36]. Aragaw et al. [53] introduced the preparation of Sn-C codoped single crystal $\mathrm{TiO}_{2}$, in which $\mathrm{SnCl}_{4}$ and glucose were used as tin and carbon dopant precursors, respectively. Qi D and coworkers reported C-doped $\mathrm{TiO}_{2} / \mathrm{MCF}-\mathrm{F}$ photocatalyst using silica mesoporous cellular foam (MCF) as host material and glucose as carbon source. Recently, our group in situ constructed C-doped $\mathrm{TiO}_{2}$ single-crystal nanorod using $\mathrm{CPS} @ \mathrm{TiO}_{2}$ as $\mathrm{TiO}_{2}$ precursor and carbon dopant source [8], this preparation process and morphology are more clearly illustrated in Figure 3.

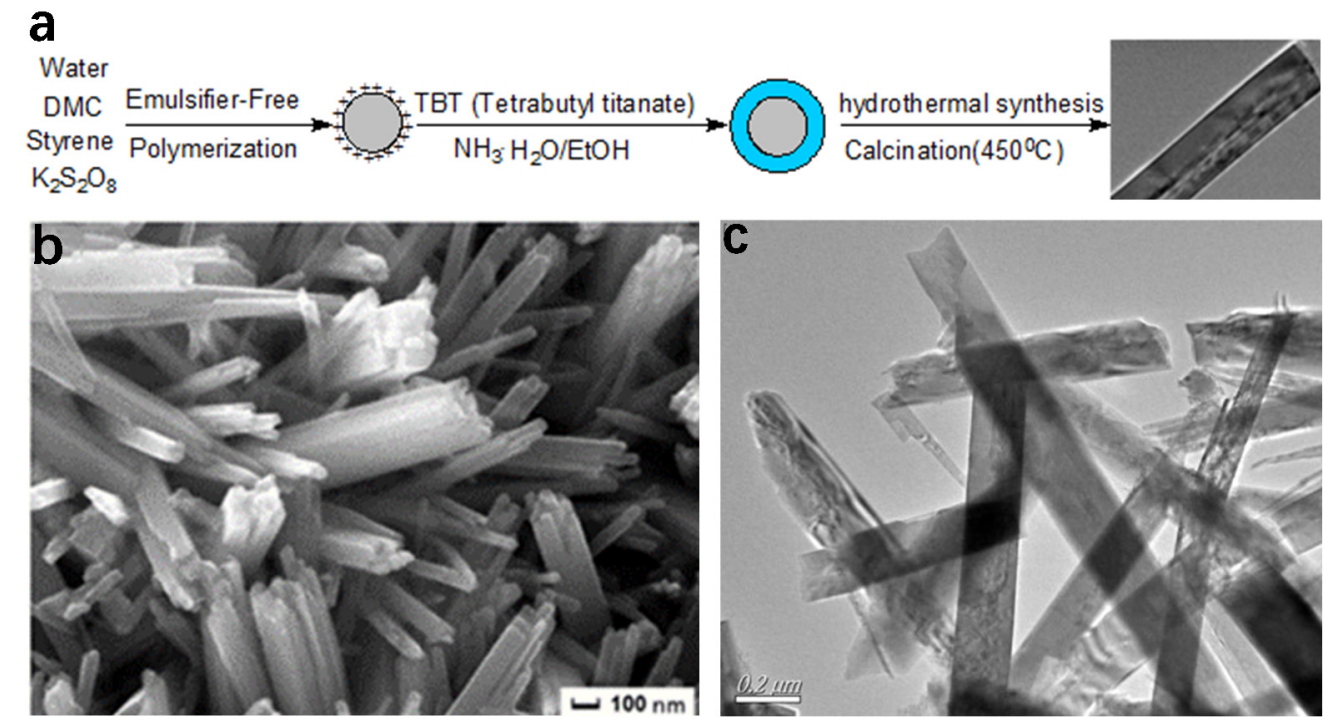

Figure 3. The demonstration (a), SEM (b), and TEM (c) of the $\mathrm{C}-\mathrm{TiO}_{2}$ single crystal nanorod. Reprinted with permission from Ref. [8].

In addition to being a one-pot and mature technique, hydrothermal method is advantageous in tuning the structure, morphology, and physical-chemical performances of final $\mathrm{TiO}_{2}$ materials by changing $\mathrm{TiO}_{2}$ precursor and hydrothermal conditions. Especially, hybrid functional $\mathrm{TiO}_{2}$-based materials can be designed and constructed by adding other required species. Although the whole preparation process seems to be very simple, each step including the selection of the titanium dioxide precursor, hydrothermal condition, washing, and calcination presents a decisive role in tuning the morphology, structure, property, and yield of $\mathrm{C}-\mathrm{TiO}_{2}$ materials [63]. 


\subsection{Template-Directed Method}

Compared with solid/nonporous titanium dioxide nanoparticles, hollow/porous $\mathrm{TiO}_{2}$ materials are more attractive because of a higher surface area and multiple interparticle scattering $[14,64]$. Precise control of the particle size, hollow/porous structure, and shell thickness of $\mathrm{TiO}_{2}$ spheres has been a pursuing object because it is a key factor determining their properties [14]. In general, two main methods are introduced to prepare hollow $\mathrm{TiO}_{2}$ spheres. One is template-free technique to construct hollow $\mathrm{TiO}_{2}$ spheres via physical phenomenon [65]. Although the strategy can realize one-pot and large-scale production, a distinguished disadvantage is the concomitant production of $\mathrm{TiO}_{2}$ spheres with an ill-shaped and fragile structure $[13,14]$. Another is the template-directed method that effectively tunes the shell and pore size of hollow $\mathrm{TiO}_{2}$ spheres, overcoming the disadvantage of the template-free technique [14]. For example, Zou et al. [48] prepared C-doped hollow $\mathrm{TiO}_{2}$ spheres using carbon sphere as a template. Matos and coworkers reported an easy and ecofriendly method to develop pristine anatase phase of $\mathrm{C}$-doped $\mathrm{TiO}_{2}$ using a biomass-derived molecule as a biotemplate [66]. Ji et al. [13] constructed C-doped $\mathrm{TiO}_{2}$ nanotubes using surface-sulfonated polystyrene as a template through calcination. Our group introduced an in situ synthetic method for the development of hierarchical $\mathrm{SiO}_{2} @ \mathrm{C}$-doped $\mathrm{TiO}_{2}$ spheres with a uniform hollow structure using cationic polystyrene spheres as templates, as shown in Figure 4 [9], and then the facile strategy was further broadened to prepare various functionalized C-doped $\mathrm{TiO}_{2}$ materials including C-doped hollow $\mathrm{TiO}_{2}$ [14], C-doped porous $\mathrm{TiO}_{2}$ [42], and C-doped $\mathrm{TiO}_{2}$ single-crystal nanorods [8]. Although the template-directed method can develop various $\mathrm{C}$-doped $\mathrm{TiO}_{2}$ materials with a regular and tuned morphology at the nano- and/or microscale via controlling the structure of templates [63], its extensive applications may be limited because of the preparation cost and insufficient characterization of templates.

a

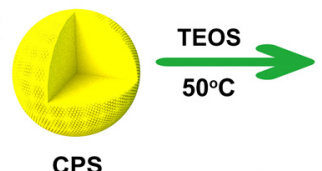

CPS

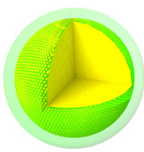

$\mathrm{CPS} @ \mathrm{SiO}_{2}$

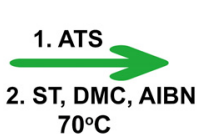

$70^{\circ} \mathrm{C}$

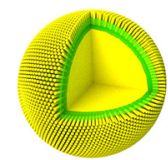

CPS@SiO $@$ @PS
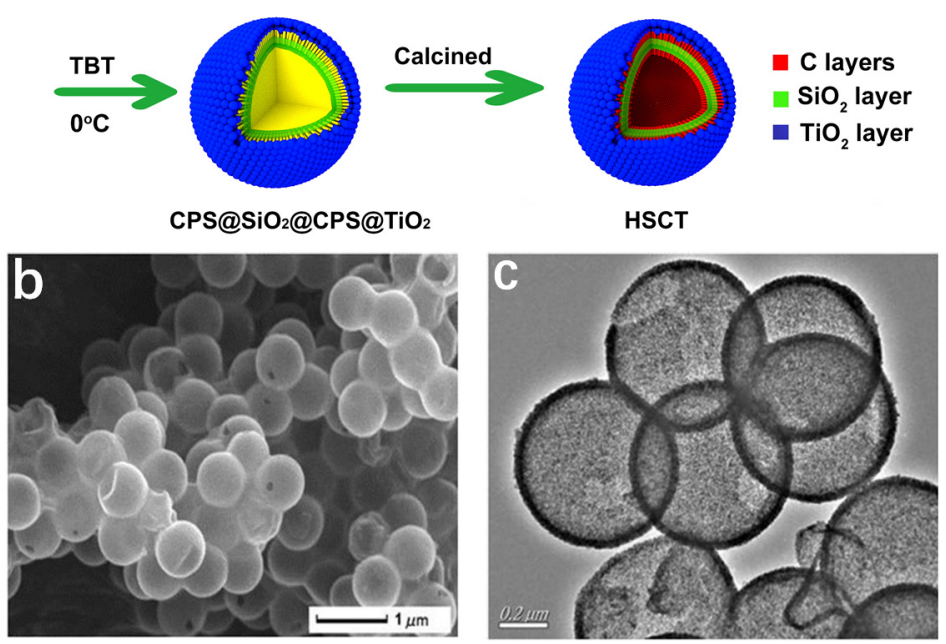

Figure 4. Preparation (a), SEM (b), and TEM (c) of the hierarchical $\mathrm{SiO}_{2} @$ C-doped $\mathrm{TiO}_{2}$ spheres. Reprinted with permission from Ref. [9].

\subsection{TiC Calcination}

Titanium carbide (TiC) holds many fascinating properties including fast electron transfer, easy modification, and superior stabilization [15,44], making it more potential for the construction of C-doped $\mathrm{TiO}_{2}$ materials via simple calcination because of its high visible-light absorption efficiency and 
fast charge transfer. Yang et al. [15] prepared a C-doped layer on the TiC nanosphere with efficient visible light-photocatalytic $\mathrm{H}_{2}$ production through in situ calcination of TiC. Figure 5 clearly demonstrated the preparation process, morphology, and structure of the as-synthesized porous C-doped $\mathrm{TiO}_{2}$. $\mathrm{Li}$ et al. [54] reported C-doped $\mathrm{TiO}_{2}$ multiple-phase composites exhibiting excellent ionic and electronic conductivity through the calcination of $\mathrm{TiC}$ at $600^{\circ} \mathrm{C}$ for $10 \mathrm{~h}$. Unfortunately, it is very difficult in preparing functionalized $\mathrm{C}$-doped $\mathrm{TiO}_{2}$ with controlled morphology, size, and hollow/porous structure via the calcination of $\mathrm{TiC}$ nanoparticle. Therefore, it is very necessary to combine other promising strategies for the development of $\mathrm{C}$-doped $\mathrm{TiO}_{2}$ materials with controllable structure and properties.

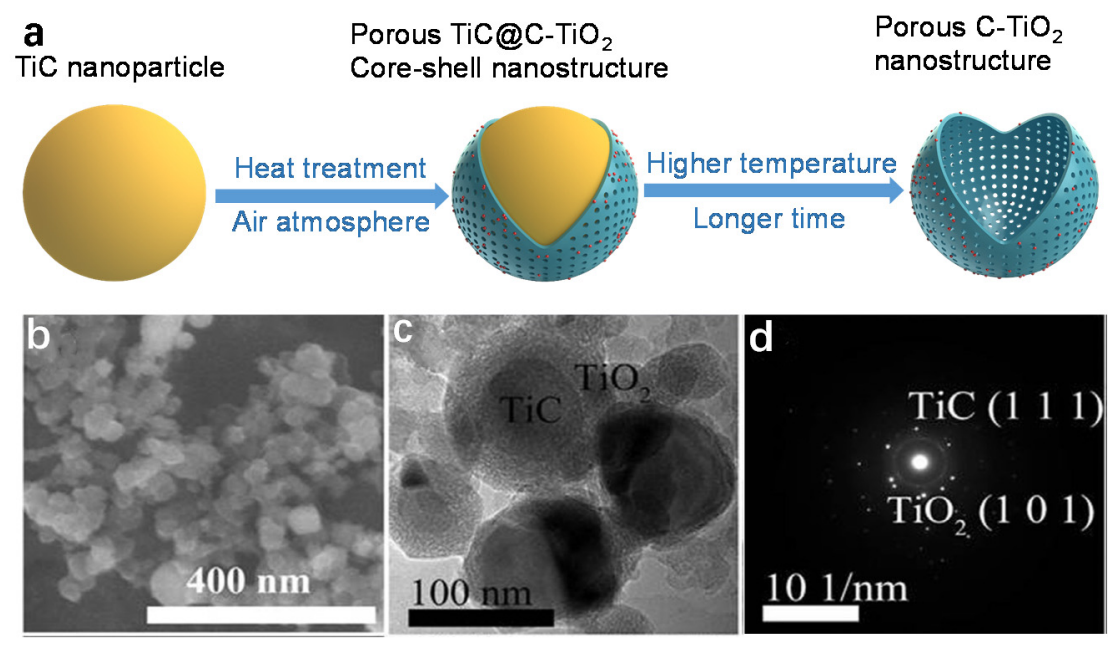

Figure 5. Preparation process (a), SEM (b), TEM (c), and SAED pattern (d) of porous $\mathrm{C}-\mathrm{TiO}_{2}$ nanostructure. Reprinted with permission from Ref. [15].

\section{Application of C-Doped $\mathrm{TiO}_{2}$ Materials}

\subsection{The Removal of Organic Pollutants}

Exploiting effective strategies to remove organic pollutants in wastewater is very necessary according to environmental safety regulations due to increasing concerns about drinking water safety $[67,68]$. Photocatalysis has been considered as a promising way to remove organic contaminants including refractory organic pollutants by using solar energy because it can mineralize various organic pollutants to produce $\mathrm{CO}_{2}, \mathrm{H}_{2} \mathrm{O}$, and other harmless small molecules. It is well known that pure $\mathrm{TiO}_{2}$ holds poor visible-light absorption, low quantum yield, and undesired recombination of photogenerated charges. Notably, C-doped $\mathrm{TiO}_{2}$ not only can effectively promote charge separation, but also can shift the optical response of $\mathrm{TiO}_{2}$ from UV to visible spectral region, leading to an enhanced photocatalytic performance for the removal of various organic pollutants (Table 2) $[8,9,39,69]$. For example, Ji et al. [13] reported that $\mathrm{C}$-doped $\mathrm{TiO}_{2}$ nanotubes demonstrated much better photocatalytic activity toward the degradation of UDMH than bare $\mathrm{TiO}_{2}$ under UV and visible light, as shown in Figure 6 . Figure $6 \mathrm{c}$ demonstrated its photodegradation mechanism: under light irradiation, photogenerated electrons transferred more efficiently to conduction band of $\mathrm{TiO}_{2}$ because carbon in the carbon- $\mathrm{TiO}_{2}$ nanotubes could act as an electron trap, inhibiting charge recombination [70,71]. Furthermore, carbon also could improve adsorption of pollutant molecules, promoting photocatalytic performance because adsorption was normally the first step in photocatalysis [67,72]. 

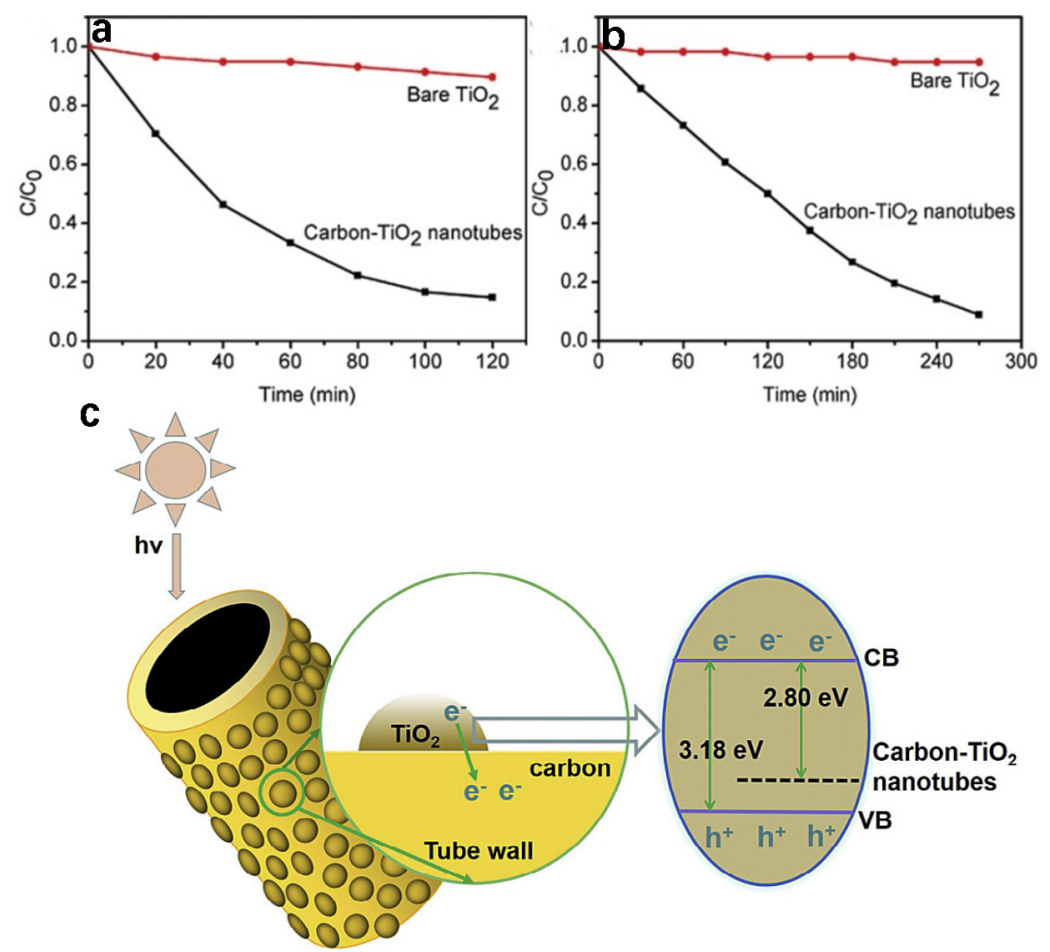

Figure 6. Photocatalytic degradation of $\mathrm{UDMH}$ solution by the carbon- $\mathrm{TiO}_{2}$ nanotubes and bare $\mathrm{TiO}_{2}$ under UV light (a), visible light (b), and photocatalytic mechanism (c). Reprinted with permission from Ref. [13].

$\mathrm{Yu}$ et al. [39] found that $\mathrm{C}$-doped $\mathrm{TiO}_{2}$ encapsulated with nano-sized graphene manifested superior visible-light performance for phenol degradation than those of anatase $\mathrm{TiO}_{2}, \mathrm{P} 25$, and bare $\mathrm{C}$-doped $\mathrm{TiO}_{2}$. Zhang et al. [5] confirmed that $\mathrm{C}$-doped $\mathrm{TiO}_{2} / \mathrm{MCFF}$ exhibited good adsorptive ability and visible-light photocatalytic performance for degrading methyl orange. Our previous works also ascertained that $\mathrm{C}$-doped $\mathrm{TiO}_{2}$-based materials manifested stronger visible-light performances toward the removal of various contaminants including rhodamine $B(\mathrm{RhB})$, methylene blue (MB), and p-nitrophenol $[8,9,14]$. The enhanced photocatalytic performance may be attributed to the synergistic effect between $\mathrm{C}$-doping and $\mathrm{TiO}_{2}$, in which carbon can generate electrons under visible light illumination, and then photoelectrons would be transferred to the contribution band of $\mathrm{TiO}_{2}$, improving its efficient light harvesting and photocatalytic activity $[17,73,74]$. It is should be pointed out that the porous/hollow structure of photocatalysts is very beneficial to increase the surface area of photocatalyst and promote the contact probability of catalyst and substrate by decreasing diffusion limitation $[9,14,75]$, which leads to better photocatalytic degradation of organic pollutants. 
Table 2. The photocatalytic performance of $\mathrm{C}$-doped $\mathrm{TiO}_{2}$ materials toward the degradation of organic pollutants.

\begin{tabular}{|c|c|c|c|c|}
\hline Catalyst & Pollutants & $\begin{array}{l}\text { Degradation } \\
\text { Rate }\end{array}$ & Enhanced Performance & Reference \\
\hline Carbon- $\mathrm{TiO}_{2}$ nanotubes & $\begin{array}{l}\text { Unsymmetrical } \\
\text { dimethylhydrazine }\end{array}$ & $90 \%$ & $10 \%$ for bare $\mathrm{TiO}_{2}$ & [13] \\
\hline Mesoporous $\mathrm{C}-\mathrm{TiO}_{2}$ & $\begin{array}{l}\text { Methylthionine } \\
\text { chloride }\end{array}$ & $100 \%$ & Improve 10 times than P25 & [75] \\
\hline C-doped anatase $\mathrm{TiO}_{2}$ & Methylene blue & $90 \%$ & 3.7 times higher than $\mathrm{TiO}_{2}$ & [66] \\
\hline C-doped ultra-small $\mathrm{TiO}_{2}$ & Toluene & $85 \%$ & $\begin{array}{c}\text { Less than } 60 \% \text { for bare } \\
\text { USTiO }_{2}\end{array}$ & [76] \\
\hline $\begin{array}{c}\mathrm{C} \text {-doped } \mathrm{TiO}_{2} / \alpha-\mathrm{Fe}_{2} \mathrm{O}_{3} \\
\text { heterojunction }\end{array}$ & Bisphenol A & $79 \%$ & $\begin{array}{l}2.7 \text { times higher than } \\
\text { pristine } \mathrm{TiO}_{2}\end{array}$ & [77] \\
\hline $\begin{array}{l}\text { C-doped } \mathrm{TiO}_{2} / \text { anatase } \\
\text { (A)/rutile (R) }\end{array}$ & Nonylphenol & $41 \%$ & $8 \%$ for undoped $\mathrm{TiO}_{2}$ & [78] \\
\hline $\mathrm{C} / \mathrm{N}$-doped $\mathrm{TiO}_{2}$ & Microplastics (MPs) & $71.77 \pm 1.88 \%$ & $\begin{array}{l}\text { Combined effect of } \mathrm{pH} \text { and } \\
\text { temperature driving the } \\
\text { photodegradation of MPs }\end{array}$ & [79] \\
\hline $\mathrm{C}-\mathrm{TiO}_{2}$ & Rhodamine B & $83.3 \%$ (75 min) & $\begin{array}{c}\text { Around } 15.0 \% \text { higher than } \\
\text { that of } \mathrm{P}-25\end{array}$ & [80] \\
\hline $\begin{array}{l}\text { Carbon doping and } \\
\text { coating of } \mathrm{TiO}_{2}\end{array}$ & Methylene blue & $85 \%$ & $\begin{array}{l}5 \text { times higher than } \\
\text { pristine } \mathrm{TiO}_{2}\end{array}$ & [81] \\
\hline Carbon-doped $\mathrm{TiO}_{2}$ & Caffeic Acid & $92 \%$ & $\begin{array}{l}\text { High adsorption and } \\
\text { degradation }\end{array}$ & [82] \\
\hline $\mathrm{N} / \mathrm{C}$ co-doped $\mathrm{TiO}_{2}$ & $\begin{array}{l}\text { Fluoroquinolone } \\
\text { antibiotics (LEV) }\end{array}$ & $95.7 \%$ & $\begin{array}{c}\text { No visible light activity for } \\
\text { Degussa P25 }\end{array}$ & [83] \\
\hline $\begin{array}{l}\mathrm{S}, \mathrm{N} \text { and } \mathrm{C} \text { doped } \\
\text { mesoporous anatase } \\
\text { brookite } \mathrm{TiO}_{2}\end{array}$ & Microcystic toxins & $100 \%$ & $12.2 \%$ for un-doped $\mathrm{TiO}_{2}$ & [84] \\
\hline $\mathrm{TiO}_{2} @ \mathrm{C}$ microspheres & Congo red & $94 \%$ & $\begin{array}{l}2.7 \text { times higher than } \\
\qquad \mathrm{N}-\mathrm{TiO}_{2}\end{array}$ & [16] \\
\hline Carbon-doped $\mathrm{TiO}_{2}$ film & Methyl ethyl ketone & $94 \%$ & $41 \%$ for $\mathrm{P} 25$ & [85] \\
\hline
\end{tabular}

\subsection{Electrochemical Application}

A variety of experiments have been proved that $\mathrm{TiO}_{2}$ is a very promising electrode material for electrochemical applications due to its low cost, ideal capacitive response, and good cyclic stability [42,86-88], however, $\mathrm{TiO}_{2}$ has many disadvantages including low conductivity, fast charge recombination, and high photochemical stability, leading to a poor electrochemical performance $[48,55,89,90]$. The introduction of carbon doping is a potential tool to efficiently improve the electrical conductivity of $\mathrm{TiO}_{2}$-based materials because carbon holds good corrosion resistance, cyclic stability, and a long service lifetime during charge/discharge processes [58,86,87], as shown in Table 3. Shen et al. [86] found that hierarchical carbon-doped $\mathrm{TiO}_{2}$ beads featured higher electronic conductivity than $\mathrm{P} 25$ and anatase $\mathrm{TiO}_{2}$ beads. Our previous work also demonstrated that $\mathrm{C}$-doped porous $\mathrm{TiO}_{2}$ electrodes [42] increased ion diffusion channels and accelerated ion transfer, leading to an enhanced electrochemical performance, as shown in Figure 7. Notably, mesoporous/hollow electrode materials can exhibit high accessible area and ionic transport $[11,36,42,58]$, resulting in enhanced electrochemical performances. Besides, the synergistic effect of multicomponent materials is of significance in promoting the electrochemical properties of carbon-doped $\mathrm{TiO}_{2}[50,56,91,92]$. 
Table 3. The photocatalytic performance of $\mathrm{C}$-doped $\mathrm{TiO}_{2}$ materials toward the degradation of organic pollutants.

\begin{tabular}{|c|c|c|c|c|c|}
\hline $\begin{array}{l}\text { Electrode } \\
\text { Materials }\end{array}$ & $\begin{array}{l}\text { Application } \\
\text { Fields }\end{array}$ & Advantage & $\begin{array}{l}\text { Comparative } \\
\text { Performance }\end{array}$ & Stability & Reference \\
\hline $\begin{array}{c}\text { MC-Meso } \\
\text { C-doped } \mathrm{TiO}_{2} / \mathrm{S}\end{array}$ & $\begin{array}{l}\text { Lithium-sulfur } \\
\text { batteries }\end{array}$ & $802 \mathrm{mAh} \mathrm{g}^{-1}$ & $\begin{array}{l}530 \mathrm{mAh} \mathrm{g}^{-1} \text { for } \\
\text { mesoporous } \\
\text { C-doped } \mathrm{TiO}_{2} / \mathrm{S}\end{array}$ & $\begin{array}{c}97.1 \% \text { after } 140 \\
\text { cycles }\end{array}$ & [36] \\
\hline $\begin{array}{l}\mathrm{N} \& \mathrm{C} \text { doped } \mathrm{TiO}_{2} \\
\text { supported } \mathrm{Pt}\end{array}$ & Fuel cells & $980 \mathrm{~mW} \mathrm{~cm}^{-2}$ & $\begin{array}{c}470 \mathrm{~mW} \mathrm{~cm}^{-2} \text { for } \\
\mathrm{Pt} / \mathrm{TiON}-1\end{array}$ & $\begin{array}{c}\text { Durability test } \\
\text { over } 50,000 \\
\text { cycles }\end{array}$ & [50] \\
\hline $\begin{array}{l}\mathrm{Si} / \mathrm{TiO}_{2}-\mathrm{CC} \\
\text { composite }\end{array}$ & $\begin{array}{l}\text { Lithium-ion } \\
\text { battery }\end{array}$ & $3.21 \mathrm{mAh} \mathrm{cm}^{-2}$ & $\begin{array}{c}\text { More excellent } \\
\text { areal capacity than } \\
\text { other silicon } \\
\text { composite anodes }\end{array}$ & $\begin{array}{l}\text { Maintain } 94.5 \% \\
\text { after } 100 \text { cycles }\end{array}$ & [92] \\
\hline $\begin{array}{c}\text { Carbon-Doped } \\
\mathrm{TiO}_{2} \text {-Bronze } \\
\text { Nanowires }\end{array}$ & $\begin{array}{l}\text { Lithium-ion } \\
\text { Batteries }\end{array}$ & $345 \mathrm{mAh} \mathrm{g}^{-1}$ & $\begin{array}{c}342 \mathrm{mAh} \mathrm{g}^{-1} \text { for } \\
\text { TB-NWs }\end{array}$ & $\begin{array}{l}\text { Maintain } 89 \% \\
\text { after } 1000 \\
\text { cycles }\end{array}$ & [93] \\
\hline $\begin{array}{c}\mathrm{TiO}_{2} @ \mathrm{C} \\
\text { nanosheets }\end{array}$ & $\begin{array}{l}\text { Na-ion } \\
\text { batteries }\end{array}$ & $264.9 \mathrm{mAh} \mathrm{g}^{-1}$ & $\begin{array}{l}170.8 \mathrm{mAh} \mathrm{g}^{-1} \text { for } \\
\text { pure carbon }\end{array}$ & $\begin{array}{l}\text { After } 100 \text { cycles } \\
\text { at } 100 \mathrm{~mA} \mathrm{~g}^{-1}\end{array}$ & [11] \\
\hline $\begin{array}{l}\text { S/C co-doped } \\
\text { anatase }\end{array}$ & $\begin{array}{l}\text { Lithium ion } \\
\text { storage }\end{array}$ & $210 \mathrm{mAh} \mathrm{g}^{-1}$ & $\begin{array}{c}\text { Better } \\
\text { electrochemical } \\
\text { performance than } \\
\text { non-doped } \mathrm{TiO}_{2}\end{array}$ & $\begin{array}{l}83 \% \text { capacity } \\
\text { retention for } \\
500 \text { cycles }\end{array}$ & [56] \\
\hline $\begin{array}{c}\text { C-doped Hollow } \\
\mathrm{TiO}_{2}\end{array}$ & Supercapacitor & $418 \mathrm{Fg}^{-1}$ & $283 \mathrm{~F} \mathrm{~g}^{-1}$ for P25 & $\begin{array}{l}78.1 \% \text { capacity } \\
\text { retention for } \\
10,000 \text { cycles }\end{array}$ & [94] \\
\hline $\begin{array}{l}\text { C-doped porous } \\
\mathrm{TiO}_{2}\end{array}$ & Supercapacitor & $485 \mathrm{~F} \mathrm{~g}^{-1}$ & $283 \mathrm{~F} \mathrm{~g}^{-1}$ for P25 & $\begin{array}{l}\sim 70 \% \text { capacity } \\
\text { retention for } \\
1000 \text { cycles }\end{array}$ & [42] \\
\hline
\end{tabular}
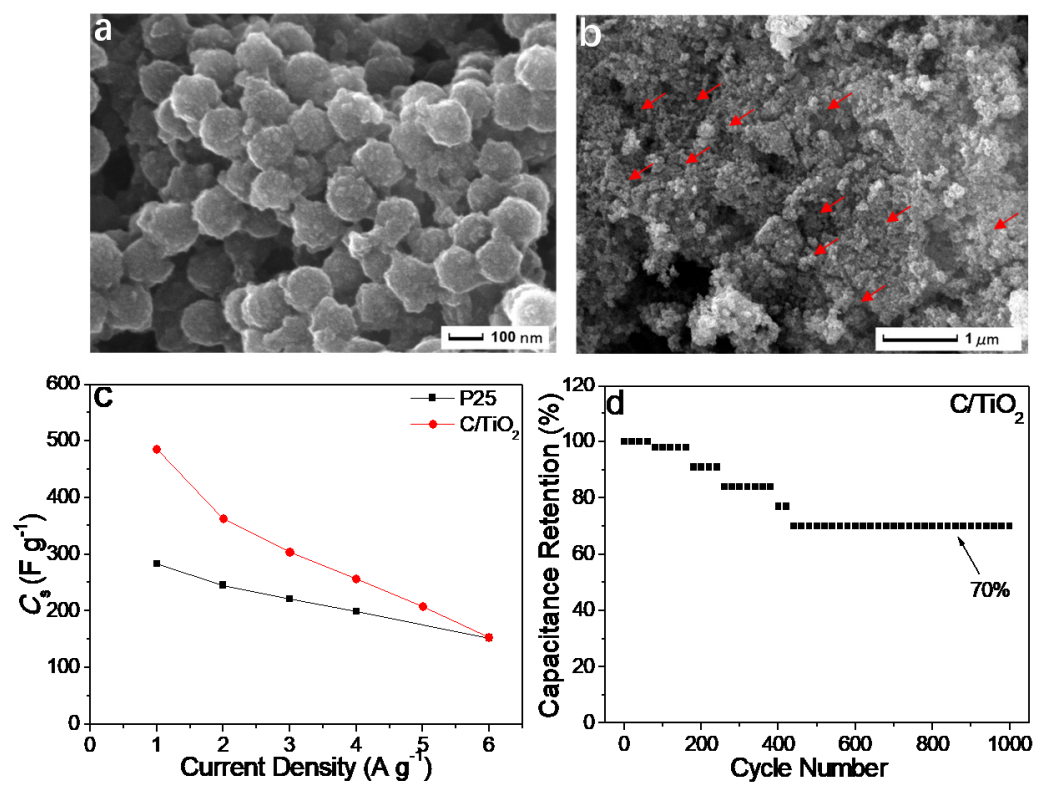

Figure 7. $\mathrm{SEM}(\mathbf{a}, \mathbf{b})$ mages of $\mathrm{C}$-doped porous $\mathrm{TiO}_{2}$ electrodes, (c) comparative specific capacitances, and (d) cycling performance over 1000 cycles. Reprinted with permission from Ref. [42].

\section{Summary and Outlook}

Although carbon doping can efficiently enhance photoelectrochemical properties of $\mathrm{TiO}_{2}$, it is still a very challenging task in obtaining a high doping amount of carbon in the $\mathrm{TiO}_{2}$ lattice because C-doped $\mathrm{TiO}_{2}$ is probably more difficult to be prepared than other non-mental doping [16], especially for 
single crystal or single-crystal-like $\mathrm{TiO}_{2}$ due to its high crystallinity $[8,91]$, which hinders its further applications in environmental, energy, and catalytic fields. Co-doping with two or more dopants is a promising way to further enhance the properties of $\mathrm{TiO}_{2}$ compared to their single doped or undoped $\mathrm{TiO}_{2}$ counterparts due to a strong synergistic effect between these codopants within the $\mathrm{TiO}_{2}$ matrix $[53,95,96]$. Zegeye et al. [36] reported that $\mathrm{MC}$-Meso C-dopedTiO $/ \mathrm{S}$ showed the best cycling stability and enhanced electrochemical property for lithium-sulfur batteries. Zhou et al. [7] found that $\mathrm{In}_{2} \mathrm{O}_{3}$ and carbon codoped $\mathrm{TiO}_{2}$ could oxidize $\mathrm{Hg}^{0}$ and manifested higher visible-light photoactivity compared with $\mathrm{P} 25$. Our previous works showed that $\mathrm{C} / \mathrm{N}-\mathrm{TiO}_{2}$ hollow sphere [95] and $\mathrm{C} / \mathrm{Bi}^{-} \mathrm{TiO}_{2}$ single crystal nanorod [97] both exhibited an enhanced photocatalytic performance toward the removal of refractory organic pollutants. Unfortunately, it is extremely difficult in figuring out the contribution of carbon doping in codoped $\mathrm{TiO}_{2}$-based materials. On the other hand, how to obtain uniform dispersion of carbon doping in the $\mathrm{TiO}_{2}$ lattice also remains a big challenge [86]. Therefore, it is envisioned that future research will provide new insights in optimizing existing strategies and developing new techniques, which better construct $\mathrm{C}$-doped $\mathrm{TiO}_{2}$ materials with a high doping amount and controlled distribution of carbon.

Author Contributions: Conceptualization, L.H. and S.C.; data curation, S.C. and Z.Y.; original draft preparation, L.H.; writing - review and editing, S.C. and Z.Y.; supervision, S.C.; project administration, S.C. All authors have read and agreed to the published version of the manuscript.

Funding: The authors would like to thank the "Blue Project" in Jiangsu Colleges and Universities (2019-69) for financial supports to carry out this work.

Conflicts of Interest: The authors declare no conflict of interest.

\section{References}

1. Li, X.; Yu, J.; Jaroniec, M. Hierarchical photocatalysts. Chem. Soc. Rev. 2016, 45, 2603-2636. [CrossRef]

2. Liu, S.; Tang, Z.; Sun, Y.; Colmenares, J.C.; Xu, Y. One-dimension-based spatially ordered architectures for solar energy conversion. Chem. Soc. Rev. 2015, 44, 5053-5075. [CrossRef] [PubMed]

3. Zhao, S.; Chen, J.; Liu, Y.; Jiang, Y.; Jiang, C.; Yin, Z.; Xiao, Y.; Cao, S. Silver Nanoparticles Confined in Shell-in-Shell Hollow $\mathrm{TiO}_{2}$ Manifesting Efficiently Photocatalytic Activity and Stability. Chem. Eng. J. 2019, 367, 249-259. [CrossRef]

4. Shi, Q.; Zhang, Y.; Sun, D.; Zhang, S.; Tang, T.; Zhang, X.; Cao, S. Bi2O3-Sensitized TiO2 Hollow Photocatalyst Drives the Efficient Removal of Tetracyclines under Visible Light. Inorgan. Chem. 2020. [CrossRef]

5. Qi, D.; Xing, M.; Zhang, J. Hydrophobic Carbon-Doped $\mathrm{TiO}_{2} / \mathrm{MCF}$ F Composite as a High Performance Photocatalyst. J. Physical. Chem. C 2014, 118, 7329-7336. [CrossRef]

6. Yin, Z.; Xie, L.; Cao, S.; Xiao, Y.; Chen, G.; Jiang, Y.; Wei, W.; Wu, L. Ag/Ag2O confined visible-light driven catalyst for highly efficient selective hydrogenation of nitroarenes in pure water medium at room temperature. Chem. Eng. J. 2020, 394, 125036. [CrossRef]

7. Zhou, X.; Wu, J.; Li, Q.; Zeng, T.; Ji, Z.; He, P.; Pan, W.; Qi, X.; Wang, C.; Liang, P. Carbon decorated $\mathrm{In}_{2} \mathrm{O}_{3} / \mathrm{TiO}_{2}$ heterostructures with enhanced visible light-driven photocatalytic activity. J. Catal. 2017, 355, 26-39. [CrossRef]

8. Shao, J.; Sheng, W.; Wang, M.; Li, S.; Chen, J.; Zhang, Y.; Cao, S. In situ synthesis of carbon-doped $\mathrm{TiO}_{2}$ single-crystal nanorods with a remarkably photocatalytic efficiency. Appl. Catal. B Environ. 2017, 209, 311-319. [CrossRef]

9. Zhang, Y.; Chen, J.; Hua, L.; Li, S.; Zhang, X.; Sheng, W.; Cao, S. High photocatalytic activity of hierarchical $\mathrm{SiO}_{2} @ \mathrm{C}$-doped $\mathrm{TiO}_{2}$ hollow sphere in $\mathrm{UV}$ and visible light towards degradation rhodamine B. J. Hazard. Mater. 2017, 340, 309-318. [CrossRef]

10. Guo, Q.; Zhou, C.; Ma, Z.; Ren, Z.; Fan, H.; Yang, X. Elementary photocatalytic chemistry on $\mathrm{TiO}_{2}$ surfaces. Chem. Soc. Rev. 2016, 45, 3701-3730. [CrossRef]

11. Zhang, Q.; He, H.; Huang, X.; Yan, J.; Tang, Y.; Wang, H. TiO $@$ @C nanosheets with highly exposed (001) facets as a high-capacity anode for Na-ion batteries. Chem. Eng. J. 2018, 332, 57-65. [CrossRef]

12. Wang, W.; Xu, D.; Cheng, B.; Yu, J.; Jiang, C. Hybrid carbon@ $\mathrm{TiO}_{2}$ hollow spheres with enhanced photocatalytic $\mathrm{CO}_{2}$ reduction activity. J. Mater. Chem. A 2017, 5, 5020-5029. [CrossRef] 
13. Ji, L.; Zhang, Y.; Miao, S.; Gong, M.; Liu, X. In situ synthesis of carbon doped $\mathrm{TiO}_{2}$ nanotubes with an enhanced photocatalytic performance under UV and visible light. Carbon 2017, 125, 544-550. [CrossRef]

14. Zhang, Y.; Zhao, Z.; Chen, J.; Cheng, L.; Chang, J.; Sheng, W.; Hu, C.; Cao, S. C-doped Hollow TiO 2 Spheres: In situ Synthesis, Controlled Shell Thickness, and Superior Visible-light Photocatalytic Activity. Appl. Catal. B Environ. 2015, 165, 715-722. [CrossRef]

15. Yang, C.; Zhang, X.; Qin, J.; Shen, X.; Yu, R.; Ma, M.; Liu, R. Porous carbon-doped $\mathrm{TiO}_{2}$ on $\mathrm{TiC}_{\text {nanostructures }}$ for enhanced photocatalytic hydrogen production under visible light. J. Catal. 2017, 347, 36-44. [CrossRef]

16. Guo, H.; Zheng, Z.; Chen, J.; Weng, W.; Huang, M. Facile template-free one-pot fabrication of $\mathrm{TiO}_{2} @ \mathrm{C}$ microspheres with high visible-light photocatalytic degradation activity. J. Ind. Eng. Chem. 2016, 36, 306-313. [CrossRef]

17. Liu, J.; Zhang, Q.; Yang, J.; Ma, H.; Tade, M.O.; Wang, S.; Liu, J. Facile synthesis of carbon-doped mesoporous anatase $\mathrm{TiO}_{2}$ for the enhanced visible-light driven photocatalysis. Chem. Commun. 2014, 50, 13971-13974. [CrossRef]

18. Shao, Y.; Cao, C.; Chen, S.; He, M.; Fang, J.; Chen, J.; Li, X.; Li, D. Investigation of nitrogen doped and carbon species decorated $\mathrm{TiO}_{2}$ with enhanced visible light photocatalytic activity by using chitosan. Appl. Catal. B Environ. 2015, 179, 344-351. [CrossRef]

19. Jia, J.; Li, D.; Wan, J.; Yu, X. Characterization and mechanism analysis of graphite/C-doped $\mathrm{TiO}_{2}$ composite for enhanced photocatalytic performance. J. Ind. Eng. Chem. Res. 2016, 33, 162-169. [CrossRef]

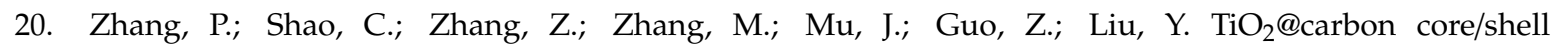
nanofibers: Controllable preparation and enhanced visible photocatalytic properties. Nanoscale 2011, 3, 2943-2949. [CrossRef]

21. Choi, H.; Kim, J.; Kim, H.; Lee, S.; Lee, Y. Improving the Electrochemical Performance of Hybrid Supercapacitor using Well-organized Urchin-like $\mathrm{TiO}_{2}$ and Activated Carbon. Electrochim. Acta 2016, 208, 202-210. [CrossRef]

22. Ribeiro, E.; Plantard, G.; Teyssandier, F.; Maury, F.; Sadiki, N.; Chaumont, D.; Goetz, V. Activated-carbon/TiO 2 composites preparation: An original grafting by milling approach for solar water treatment applications. J. Environ. Chem. Eng. 2020, 8, 104115. [CrossRef]

23. Cao, N.; Gu, M.; Gao, M.; Li, C.; Liu, K.; Zhao, X.; Feng, J.; Ren, Y.; Wei, T. A three-layer photocatalyst carbon fibers $/ \mathrm{TiO}_{2}$ seed/ $/ \mathrm{TiO}_{2}$ nanorods with high photocatalytic degradation under visible light. Appl. Surf. Sci. 2020, 530, 147289. [CrossRef]

24. Huo, J.; Xue, Y.; Wang, X.; Liu, Y.; Zhang, L.; Guo, S. TiO 2 /carbon nanofibers doped with phosphorus as anodes for hybrid Li-ion capacitors. J. Power Source 2020, 473, 228551. [CrossRef]

25. Naoi, K.; Kurita, T.; Abe, M.; Furuhashi, T.; Abe, Y.; Okazaki, K.; Miyamoto, J.; Iwama, E.; Aoyagi, S.; Naoi, W.; et al. Ultrafast Nanocrystalline- $\mathrm{TiO}_{2}(\mathrm{~B}) /$ Carbon Nanotube Hyperdispersion Prepared via Combined Ultracentrifugation and Hydrothermal Treatments for Hybrid Supercapacitors. Adv. Mater. 2016, 28, 6751-6757. [CrossRef] [PubMed]

26. Song, L.; Chen, P.; Li, Z.; Du, P.; Yang, Y.; Li, N.; Xiong, J. Flexible carbon nanotubes $/ \mathrm{TiO}_{2} / \mathrm{C}$ nanofibrous film as counter electrode of flexible quasi-solid dye-sensitized solar cells. Thin Solid Films 2020, 711, 138307. [CrossRef]

27. Basha, G.M.T.; Srikanth, A.; Venkateshwarlu, B. Effect of reinforcement of carbon nanotubes on air plasma sprayed conventional $\mathrm{Al}_{2} \mathrm{O}_{3}-3 \% \mathrm{TiO}_{2}$ ceramic coatings. Mater. Today Proceed 2020, 20, 191-194. [CrossRef]

28. Wu, H.; Wu, X.; Wang, Z.; Aoki, H.; Kutsuna, S.; Jimura, K.; Hayashi, S. Anchoring titanium dioxide on carbon spheres for high-performance visible light photocatalysis. Appl. Catal. B Environ. 2017, 207, 255-266. [CrossRef]

29. Yao, J.; Mei, T.; Cui, Z.; Yu, Z.; Xu, K.; Wang, X. Hollow carbon spheres with $\mathrm{TiO}_{2}$ encapsulated sulfur and polysulfides for long-cycle lithium-sulfur batteries. Chem. Eng. J. 2017, 330, 644-650. [CrossRef]

30. Cheng, C.; Tan, X.; Lu, D.; Wang, L.; Sen, T.; Lei, J.; El-Toni, A.M.; Zhang, J.; Zhang, F.; Zhao, D. Carbon-Dot-Sensitized, Nitrogen-Doped $\mathrm{TiO}_{2}$ in Mesoporous Silica for Water Decontamination through Nonhydrophobic Enrichment-Degradation Mode. Chem. Eng. J. 2015, 21, 17944-17950.

31. Shahnazi, A.; Nabid, M.R.; Sedghi, R. Synthesis of surface molecularly imprinted poly-o-phenylenediamine/ $\mathrm{TiO}_{2} /$ carbon nanodots with a highly enhanced selective photocatalytic degradation of pendimethalin herbicide under visible light. React. Funct. Polym. 2020, 151, 104580. [CrossRef] 
32. Zhang, Y.; Foster, C.W.; Banks, C.E.; Shao, L.; Hou, H.; Zou, G.; Chen, J.; Huang, Z.; Ji, X. Graphene-Rich Wrapped Petal-Like Rutile $\mathrm{TiO}_{2}$ tuned by Carbon Dots for High-Performance Sodium Storage. Adv Mater. 2016, 28, 9391-9399. [CrossRef] [PubMed]

33. Xu, C.; Kou, X.; Cao, B.; Fang, H. Hierarchical graphene@ $\mathrm{TiO}_{2}$ sponges for sodium-ion storage with high areal capacity and robust stability. Electrochim. Acta 2020, 355, 136782. [CrossRef]

34. Sadeghian, Z.; Hadidi, M.R.; Salehzadeh, D.; Nemati, A. Hydrophobic octadecylamine-functionalized graphene/ $/ \mathrm{TiO}_{2}$ hybrid coating for corrosion protection of copper bipolar plates in simulated proton exchange membrane fuel cell environment. Int. J. Hydrogen Energ. 2020, 45, 15380-15389. [CrossRef]

35. Wang, G.; Feng, H.; Hu, L.; Jin, W.; Hao, Q.; Gao, A.; Peng, X.; Li, W.; Wong, K.; Wang, H.; et al. An antibacterial platform based on capacitive carbon-doped $\mathrm{TiO}_{2}$ nanotubes after direct or alternating current charging. Nat. Commun. 2018, 9, 2055. [CrossRef] [PubMed]

36. Zegeye, T.A.; Kuo, C.J.; Wotango, A.S.; Pan, C.; Chen, H.; Haregewoin, A.M.; Cheng, J.; Su, W.; Hwang, B. Hybrid nanostructured microporous carbon-mesoporous carbon doped titanium dioxide/sulfur composite positive electrode materials for rechargeable lithium-sulfur batteries. J. Power Sources 2016, 32, 239-252. [CrossRef]

37. Trevisan, V.; Olivo, A.; Pinna, F.; Signoretto, M.; Vindigni, F.; Cerrato, G.; Bianchi, C.L. C-N/TiO 2 photocatalysts: Effect of co-doping on the catalytic performance under visible light. Appl. Catal. B Environ. 2014, 160, 152-160. [CrossRef]

38. Cao, S.; Liu, B.; Deng, X.; Luo, R.; Chen, H. A novel approach for the preparation of acrylate-siloxane particles with core-shell structure. Polym. Int. 2006, 56, 357-363. [CrossRef]

39. Yu, S.; Yun, H.; Kim, Y.; Yi, J. Carbon-doped $\mathrm{TiO}_{2}$ nanoparticles wrapped with nanographene as a high performance photocatalyst for phenol degradation under visible light irradiation. Appl. Catal. B Environ. 2014, 144, 893-899. [CrossRef]

40. Zeng, L.; Song, W.; Li, M.; Zeng, D.; Xie, C. Catalytic oxidation of formaldehyde on surface of $\mathrm{H} \mathrm{TiO}_{2} / \mathrm{H} \mathrm{C}$ $\mathrm{TiO}_{2}$ without light illumination at room temperature. Appl. Catal. B Environ. 2014, 147, 490-498. [CrossRef]

41. Liu, J.; Han, L.; An, N.; Xing, L.; Ma, H.; Cheng, L.; Yang, J.; Zhang, Q. Enhanced visible-light photocatalytic activity of carbonate-doped anatase $\mathrm{TiO}_{2}$ based on the electron-withdrawing bidentate carboxylate linkage. Appl. Catal. B Environ. 2017, 202, 642-652. [CrossRef]

42. Chen, J.; Qiu, F.; Zhang, Y.; Liang, J.; Zhu, H.; Cao, S. Enhanced supercapacitor performances using C-doped porous $\mathrm{TiO}_{2}$ electrodes. Appl. Surf. Sci. 2015, 356, 553-560. [CrossRef]

43. Payormhorm, J.; Idem, R. Synthesis of C-doped $\mathrm{TiO}_{2}$ by sol-microwave method for photocatalytic conversion of glycerol to value-added chemicals under visible light. Appl. Catal. A Gen. 2020, 590, 117362. [CrossRef]

44. Cao, S.; Xue, Z.; Yang, C.; Qin, J.; Zhang, L.; Yu, P.; Wang, S.; Zhao, Y.; Zhang, X.; Liu, R. Insights into the Li+ storage mechanism of TiC@C-TiO2core-shell nanostructures as high performance anodes. Nano Energy 2018, 50, 25-34. [CrossRef]

45. Liu, G.; He, F.; Zhang, J.; Li, L.; Li, F.; Chen, L.; Huang, Y. Yolk-shell structured $\mathrm{Fe}_{3} \mathrm{O}_{4} @ \mathrm{C} @ \mathrm{~F}-\mathrm{TiO}_{2}$ microspheres with surface fluorinated as recyclable visible-light driven photocatalysts. Appl. Catal. B Environ. 2014, 150-151, 515-522. [CrossRef]

46. Qin, Y.; Zhuang, Y.; Lv, R.; Wang, T.; Wang, W.; Wang, C. Pd nanoparticles anchored on carbon-doped $\mathrm{TiO}_{2}$ nanocoating support for ethanol electrooxidation in alkaline media. Electrochim. Acta 2015, 154, 77-82. [CrossRef]

47. Zhao, D.; Zhang, X.; Sui, L.; Wang, W.; Zhou, X.; Cheng, X.; Gao, S.; Xu, Y.; Huo, L. C-doped TiO 2 nanoparticles to detect alcohols with different carbon chains and their sensing mechanism analysis. Sens. Actuat B Chem. 2020, 312, 127942. [CrossRef]

48. Zou, Y.; Shi, J.; Ma, D.; Fan, Z.; Lu, L.; Niu, C. In situ synthesis of C-doped $\mathrm{TiO}_{2} @ g-\mathrm{C}_{3} \mathrm{~N}_{4}$ core-shell hollow nanospheres with enhanced visible-light photocatalytic activity for $\mathrm{H}_{2}$ evolution. Chem. Eng. J 2017, 322, 435-444. [CrossRef]

49. Yang, C.; Qin, J.; Xue, Z.; Ma, M.; Zhang, X.; Liu, R. Rational design of carbon-doped $\mathrm{TiO}_{2}$ modified g- $\mathrm{C}_{3} \mathrm{~N}_{4}$ via in-situ heat treatment for drastically improved photocatalytic hydrogen with excellent photostability. Nano Energy 2017, 41, 1-9. [CrossRef]

50. Dhanasekaran, P.; Selvaganesh, S.; Bhat, S.D. Nitrogen and carbon doped titanium oxide as an alternative and durable electrocatalyst support in polymer electrolyte fuel cells. J. Power Sources 2016, 304, 360-372. [CrossRef] 
51. Han, X.; An, L.; Hu, Y.; Li, Y.; Hou, C.; Wang, H.; Zhang, Q. Ti $3_{3}-C_{2}$ MXene-derived carbon-doped TiO 2 coupled with $\mathrm{g}-\mathrm{C}_{3} \mathrm{~N}_{4}$ as the visible-light photocatalysts for photocatalytic $\mathrm{H}_{2}$ generation. Appl. Catal. B Environ. 2020, 265, 118539. [CrossRef]

52. Qin, Y.; Li, Y.; Lv, R.; Wang, T.; Wang, W.; Wang, C. Enhanced methanol oxidation activity and stability of Pt particles anchored on carbon-doped $\mathrm{TiO}_{2}$ nanocoating support. J. Power Sources 2015, 278, 639-644. [CrossRef]

53. Aragaw, B.A.; Pan, C.; Su, W.; Chen, H.; Rick, J.; Hwang, B. Facile one-pot controlled synthesis of Sn and $\mathrm{C}$ codoped single crystal $\mathrm{TiO}_{2}$ nanowire arrays for highly efficient photoelectrochemical water splitting. Appl. Catal. B Environ. 2015, 163, 478-486. [CrossRef]

54. Li, Y.; Shen, J.; Li, J.; Liu, S.; Yu, D.; Xu, R.; Fu, W.; Lv, X. Constructing a novel strategy for carbon-doped TiO 2 multiple-phase nanocomposites toward superior electrochemical performance for lithium ion batteries and the hydrogen evolution reaction. J. Mater. Chem. A 2017, 5, 7055-7063. [CrossRef]

55. Ivanov, S.; Barylyak, A.; Besaha, K.; Dimitrova, A.; Krischok, S.; Bund, A.; Bobitski, J. Enhanced lithium ion storage in $\mathrm{TiO}_{2}$ nanoparticles, induced by sulphur and carbon co-doping. J. Power Sources 2016, 326, 270-278. [CrossRef]

56. Nouri, E.; Mohammadi, M.R.; Lianos, P. Impact of preparation method of $\mathrm{TiO}_{2}-\mathrm{RGO}$ nanocomposite photoanodes on the performance of dye-sensitized solar cells. Electrochim. Acta 2016, 219, 38-48. [CrossRef]

57. Guan, D.; Yu, Q.; Xu, C.; Tang, C.; Zhou, L.; Zhao, D.; Mai, L. Aerosol synthesis of trivalent titanium doped titania/carbon composite microspheres with superior sodium storage performance. Nano Res. 2017, 10, 4351-4359. [CrossRef]

58. Zhang, Y.; Zhao, Y.; Cao, S.; Yin, Z.; Cheng, L.; Wu, L. Design and Synthesis of Hierarchical $\mathrm{SiO}_{2} @ \mathrm{C} / \mathrm{TiO}_{2}$ Hollow Spheres for High-Performance Supercapacitors. ACS Appl. Mater. Interfaces 2017, 9 , 29982-29991. [CrossRef]

59. Zhang, Y.; Chen, J.; Tang, H.; Xiao, Y.; Qiu, S.; Li, S.; Cao, S. Hierarchically-structured $\mathrm{SiO}_{2}-\mathrm{Ag} @ \mathrm{TiO}_{2}$ hollow spheres with excellent photocatalytic activity and recyclability. J. Hazard. Mater. 2018, 354, 17-26. [CrossRef]

60. Yin, Z.; Qiu, S.; Chen, W.; Li, H.; Cheng, L.; Cao, S. Highly photocatalytic activity from tri-modified $\mathrm{TiO}_{2}$ hollow spheres. Mater. Let. 2018, 214, 202-204. [CrossRef]

61. Varnagiris, S.; Medvids, A.; Lelis, M.; Milcius, D.; Antuzevics, A. Black carbon-doped TiO2 films: Synthesis, characterization and photocatalysis. J. Photoch. Photobio. A 2019, 382, 111941. [CrossRef]

62. Fittipaldi, M.; Gombac, V.; Montini, T.; Fornasiero, P.; Graziani, M. A high-frequency (95 GHz) electron paramagnetic resonance study of B-doped $\mathrm{TiO}_{2}$ photocatalysts. Inorg. Chim. Acta 2008, 361, 3980-3987. [CrossRef]

63. Liu, N.; Chen, X.; Zhang, J.; Schwank, J.W. A review on $\mathrm{TiO}_{2}$-based nanotubes synthesized via hydrothermal method: Formation mechanism, structure modification, and photocatalytic applications. Catal. Today 2014, 225, 34-51. [CrossRef]

64. Murdoch, M.; Waterhouse, G.; Nadeem, M.; Metson, J.; Keane, M.; Howe, R.; Llorca, J.; Idriss, H. The effect of gold loading and particle size on photocatalytic hydrogen production from ethanol over $\mathrm{Au} / \mathrm{TiO}_{2}$ nanoparticles. Nat. Chem. 2011, 3, 489-492. [CrossRef] [PubMed]

65. Wu, N.; Wang, J.; Tafen, D.N.; Wang, H.; Zheng, J.; Lewis, J.P.; Liu, X.; Leonard, S.S. Shape-Enhanced Photocatalytic Activity of Single-Crystalline Anatase $\mathrm{TiO}_{2}$ (101) Nanobelts. J. Am. Chem. Soc. 2010, 132, 6679-6685. [CrossRef] [PubMed]

66. Matos, J.; Riquelme, J.O.; Poon, P.S.; Montana, R.; Garcia, X.; Campos, K.; Garrido, J.C.H.; Titirici, M.M. C-doped anatase $\mathrm{TiO}_{2}$ : Adsorption kinetics and photocatalytic degradation of methylene blue and phenol, and correlations with DFT estimations. J. Colloid Interface Sci. 2019, 547, 14-29. [CrossRef]

67. Chen, J.; Qiu, F.; Xu, W.; Cao, S.; Zhu, H. Recent progress in enhancing photocatalytic efficiency of $\mathrm{TiO}_{2}$-based materials. Appl. Catal. A Gen. 2015, 495, 131-140. [CrossRef]

68. Vimonses, V.; Jin, B.; Chow, C.W.K.; Saint, C. An adsorption-photocatalysis hybrid process using multi-functional-nanoporous materials for wastewater reclamation. Water Res. 2010, 44, 5385-5397. [CrossRef]

69. Lin, Y.; Weng, C.; Chen, F. Key operating parameters affecting photocatalytic activity of visible-light-induced C-doped $\mathrm{TiO}_{2}$ catalyst for ethylene oxidation. Chem. Eng. J. 2014, 248, 175-183. [CrossRef]

70. Zhang, J.; Vasei, M.; Sang, Y.; Liu, H.; Claverie, J.P. TiO $@_{2}$ carbon photocatalysts: The effect of carbon thickness on catalysis. ACS Appl. Mater. Inter. 2016, 8, 1903-1912. [CrossRef] 
71. Liu, H.; Li, W.; Shen, D.; Zhao, D.; Wang, G. Graphitic carbon conformal, coating of mesoporous $\mathrm{TiO}_{2}$ hollow spheres for high-performance lithium ion battery anodes. J. Am. Chem. Soc. 2015, 137, 13161-13166. [CrossRef] [PubMed]

72. Cheng, L.; Qiu, S.; Chen, J.; Shao, J.; Cao, S. A Practical Pathway for the preparation of $\mathrm{Fe}_{2} \mathrm{O}_{3}$ decorated $\mathrm{TiO}_{2}$ photocatalyst with enhanced visible-light photoactivity. Mater. Chem. Phys. 2017, 190, 53-61. [CrossRef]

73. Marszewski, M.; Marszewska, J.; Pylypenko, S.; Jaroniec, M. Synthesis of Porous Crystalline Doped Titania Photocatalysts Using Modified Precursor Strategy. Chem. Mater. 2016, 28, 7878-7888. [CrossRef]

74. Yuan, Y.; Ruan, Z.; Huang, X.; Jiang, Y.; Tan, H. Energy-absorption-based explanation of the $\mathrm{TiO}_{2} / \mathrm{C}$ photocatalytic activity enhancement mechanism. J. Catal. 2017, 348, 246-255. [CrossRef]

75. Wei, W.; Yu, C.; Zhao, Q.; Qian, X.; Li, G.; Wan, Y. Synergy effect in photodegradation of contaminants from water using ordered mesoporous carbon-based titania catalyst. Appl. Catal. B Environ. 2014, 146, 151-161. [CrossRef]

76. Zhao, X.; Zhang, Y.; Wu, M.; Szeto, W.; Wang, Y.; Pan, W.; Leung, D.Y.C. Carbon doped ultra-small TiO 2 coated on carbon cloth for efficient photocatalytic toluene degradation under visible LED light irradiation. Appl. Surf. Sci. 2020, 527, 146780. [CrossRef]

77. Mohamed, M.A.; Rahman, N.A.; Zain, M.F.M.; Minggu, L.J.; Kassim, M.B.; Jaafar, J.; Samad, S.; Mastuli, M.S.; Wong, R.J. Hematite microcube decorated $\mathrm{TiO}_{2}$ nanorods as heterojunction photocatalyst with in-situ carbon doping derived from polysaccharides bio-templates hydrothermal carbonization. J. Alloys Compd. 2020, 820, 153143. [CrossRef]

78. Noorimotlagh, Z.; Kazeminezhad, I.; Jaafarzadeh, N.; Ramezani, Z. Improved performance of immobilized $\mathrm{TiO}_{2}$ under visible light for the commercial surfactant degradation: Role of carbon doped $\mathrm{TiO}_{2}$ and anatase/rutile ratio. Catal. Today 2020, 348, 277-289. [CrossRef]

79. Maria, C.A.T.; Chiu, J.F.V.; López, J.M.H.; Rosa, J.R.; Barbieri, V.; Siligardi, C.; González, E.I.C. Microplastic pollution reduction by a carbon and nitrogen-doped $\mathrm{TiO}_{2}$ : Effect of $\mathrm{pH}$ and temperature in the photocatalytic degradation process. J. Hazard. Mater. 2020, 395, 122632.

80. Zhao, Y.; Li, X.; Tian, C.; Wang, J. Production of carbon-doped titanium dioxide $\left(\mathrm{C}-\mathrm{TiO}_{2}\right)$ from polytitanium-coagulated sludge as an adsorbent or photocatalyst for pollutant removals. J. Clean Prod. 2020, 267, 121979. [CrossRef]

81. Wang, Y.; Chen, Y.; Barakat, T.; Wang, T.; Krief, A.; Zeng, Y.; Laboureur, M.; Fusaro, L.; Liao, H.; Su, B. Synergistic effects of carbon doping and coating of $\mathrm{TiO}_{2}$ with exceptional photocurrent enhancement for high performance $\mathrm{H}_{2}$ production from water splitting. J. Energy Chem. 2021, 56, 141-151. [CrossRef]

82. Venditti, F.; Cuomo, F.; Ceglie, A.; Avino, P.; Russo, M.V.; Lopez, F. Visible Light Caffeic Acid Degradation by Carbon-Doped Titanium Dioxide. Langmuir 2015, 31, 3627-3634. [CrossRef] [PubMed]

83. Huang, X.; Yang, W.; Zhang, G.; Yan, L.; Zhang, Y.; Jiang, A.; Xu, H.; Zhou, M.; Liu, Z.; Tang, H.; et al. Alternative synthesis of nitrogen and carbon co-doped $\mathrm{TiO}_{2}$ for removing fluoroquinolone antibiotics in water under visible light. Catal. Today 2020. [CrossRef]

84. El-Sheikh, S.M.; Zhang, G.; El-Hosainy, H.M.; Ismail, A.A.; O'Shea, K.E.; Falaras, P.; Kontos, A.G.; Dionysiou, D.D. High performance sulfur, nitrogen and carbon doped mesoporous anatase-brookite $\mathrm{TiO}_{2}$ photocatalyst for the removal of microcystin-LR under visible light irradiation. J. Hazard. Mater. 2014, 280, 723-733. [CrossRef] [PubMed]

85. Shayegan, Z.; Haghighat, F.; Lee, C. Carbon-doped $\mathrm{TiO}_{2}$ film to enhance visible and UV light photocatalytic degradation of indoor environment volatile organic compounds. J. Environ. Chem. Eng. 2020, 8, 104162. [CrossRef]

86. Shen, Z.; Wang, G.; Tian, H.; Sunarso, J.; Liu, L.; Liu, J.; Liu, S. Bi-layer photoanode films of hierarchical carbon-doped brookite-rutile $\mathrm{TiO}_{2}$ composite and anatase $\mathrm{TiO}_{2}$ beads for efficient dye-sensitized solar cells. Electrochim. Acta 2016, 216, 429-437. [CrossRef]

87. Elmouwahidi, A.; Garcıa, E.B.; Quiben, J.C.; Cadenas, A.F.P.; Maldonado-Hodar, F.J.; Carrasco-Marın, F. Carbon- $\mathrm{TiO}_{2}$ composites as high-performance supercapacitor electrodes: Synergistic effect between carbon and metal oxide phases. J. Mater. Chem. A 2018, 6, 633-644. [CrossRef]

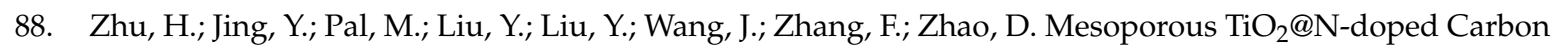
Composite Nanospheres Synthesized by Direct Carbonization of Surfactants after Sol-gel Process for Superior Lithium Storage. Nanoscale 2017, 9, 1539-1546. [CrossRef] 
89. Geng, H.; Ming, H.; Ge, D.; Zheng, J.; Gu, H. Designed fabrication of fluorine-doped carbon coated mesoporous $\mathrm{TiO}_{2}$ hollow spheres for improved lithium storage. Electrochim. Acta 2015, 157, 1-7. [CrossRef]

90. Zhu, Q.; Xie, C.; Li, H.; Yang, C.; Zeng, D. A novel planar integration ofall-solid-state capacitor and photodetector by an ultra-thin transparentsulfated $\mathrm{TiO}_{2}$ film. Nano Energy 2014, 9, 252-263. [CrossRef]

91. Yin, Z.; Shao, J.; Tang, W.; Sheng, W.; Sun, D.; Xiao, Y.; Cao, S. Design and synthesis of 'single-crystal-like' C-doped $\mathrm{TiO}_{2}$ nanorods for high-performance supercapacitors. Nanotechnology 2020, 31, 275401. [CrossRef] [PubMed]

92. Li, B.; Zhao, W.; Yang, Z.; Zhang, C.; Dang, F.; Liu, Y.; Jin, F.; Chen, X. A carbon-doped anatase TiO $2-\mathrm{Based}$ flexible silicon anode with high-performance and stability for flexible lithium-ion battery. J. Power Sources 2020, 466, 228339. [CrossRef]

93. Goriparti, S.; Miele, E.; Prato, M.; Scarpellini, A.; Marras, S.; Monaco, S.; Toma, A.; Messina, G.C.; Alabastri, A.; Angelis, F.D.; et al. Direct Synthesis of Carbon-Doped $\mathrm{TiO}_{2}-$ Bronze Nanowires as Anode Materials for High Performance Lithium-Ion Batteries. ACS Appl. Mater. Inter. 2015, 7, 25139-25146. [CrossRef] [PubMed]

94. Chen, J.; Qiu, F.; Zhang, Y.; Cao, S. Carbon-Doped Hollow Titania with Tuneable Shell Architecture for Supercapacitors. Aust. J. Chem. 2016, 69, 183-190. [CrossRef]

95. Xiao, Y.; Sun, X.; Li, L.; Chen, J.; Zhao, S.; Jiang, C.; Yang, L.; Cheng, L.; Cao, S. Simultaneous formation of a $\mathrm{C} / \mathrm{N}-\mathrm{TiO}_{2}$ hollow photocatalyst with efficient photocatalytic performance and recyclability. Chin. J. Catal. 2019, 40, 765-775. [CrossRef]

96. Hua, Z.; Dai, Z.; Bai, X.; Ye, Z.; Gu, H.; Huang, X. A facile one-step electrochemical strategy of doping iron, nitrogen, and fluorine into titania nanotube arrays with enhanced visible light photoactivity. J. Hazard. Mater. 2015, 293, 112-121. [CrossRef]

97. Tang, W.; Chen, J.; Yin, Z.; Sheng, W.; Lin, F.; Xu, H.; Cao, S. The complete removal of phenolic contaminants from bismuth-modified $\mathrm{TiO}_{2}$ single crystal photocatalyst. Chin. J. Catal. 2021, 42, 347-355. [CrossRef]

Publisher's Note: MDPI stays neutral with regard to jurisdictional claims in published maps and institutional affiliations. 